\title{
AGRESIVITAS TOKOH DALAM NOVEL JAZZ, PARFUM, DAN \\ INSIDEN KARYA SENO GUMIRA AJIDARMA
}

(Suatu Kajian Psikologi Sastra)

\author{
Dede Pratiwi Susilowati, Emzir ${ }^{1}$ \\ Universitas Negeri Jakarta, Program Pascasarjana S2 \\ Jl. Rawamangun Muka, Jakarta Timur, DKI Jakarta 13220 \\ Email : Dedepratiwi93@yahoo.com
}

\begin{abstract}
Abstrak
Penelitian ini bertujuan untuk mengetahui agresivitas tokoh dalam novel Jazz, Parfum, dan Insiden karya Seno Gumira Ajidarma dari pendekatan psikologi sastra. Penelitian ini dilakukan bulan September 2016 hingga Juli 2017. Penelitian ini merupakan penelitian kualitatif dengan menggunakan metode analisis isi, dan sumbernya adalah novel Jazz, Parfum, dan Insiden. Jenis agresivitas yang paling banyak ditemukan adalah agresivitas langsung-aktifnonverbal sejumlah $91(75,2 \%)$ data yang berupa tindakan merugikan orang lain secara langsung. Kemudian tujuan agresivitas yang paling menonjol sebanyak 7 (70\%) data, tujuan agresivitas tersebut untuk menghentikan perilaku yang tidak sesuai, tujuan ini bukan untuk menyakiti korban. Lalu, sebab munculnya agresivitas yang paling besar adalah faktor provokasi, provokasi terjadi karena berbagai pihak saling memanasi sehingga agresi muncul, faktor provokasi ini ditemukan sebanyak 3 (75\%) data. Lalu dampak agresi yang menonjol dalam penelitian ini adalah kematian, kematian terjadi karena agresi sudah terlalu parah. Dampak kematian ditemukan sebanyak $12(42,8 \%)$ data. Yang terakhir solusi mengurangi agresi paling banyak ditemukan adalah hukuman, seperti dipenjara, ditahan sebanyak 9 (90\%) data. Dalam novel Jazz, Parfum, dan Insiden terdapat nilai-nilai positif untuk membangkitkan pandangan pembaca terhadap kehidupan nyata, khususnya mengenai rasa empati, simpati pada sesama manusia.
\end{abstract}

Kata kunci: Agresivitas, Tokoh, Novel, Seno Gumira Ajidarma.

\section{The character's aggressiveness from Jazz, Parfum, and Insiden a novel by Seno Gumira Ajidarma \\ (The litelature of psychology) \\ Abstrack}

This research is purposed to analysze the character's aggresiveness from Jazz, Parfum, and Insiden, a novel by Seno Gumira Ajidarma. This research has started at September 2016 and end at July 2017. By using content analysis for it is method, this kind of research is qualitative research, on the based Jazz, Parfum, and Insiden. Some type of aggressiveness oftenly found in this research is kind of direct-active-nonverbal, amount 91 (75,2\%) data which is such action that directly disserving people. Then the dominant purposes of aggressiveness is

\footnotetext{
${ }^{1}$ Pembimbing
} 
amount 7 (70\%) data, this kind of aggressiveness takes order to stop unappropriate behaviour, not to harm victims. Then the biggest cause of aggressiveness is based on provocative factors, that appears as if each side of groups keep provoking and raise aggression up. There are 3 (75\%) datas amount this factor. Then the most dominant influence of aggression in this research is the death caused by highly ruthless aggression. This kind of death influence is amount 12 (42,8\%) data. The last is the mostly solution found to ease aggressiveness is punishment, which are imprisoned or arrested, amount 9 (90\%) datas of them. In the Jazz, Parfum, and Insiden novel, there are positive values to raise up the readers perspective about reality, some of them are especially empathy, and sympathy among human beings.

Keywords: aggressiveness, aggression, character, novel, Seno Gumira Ajidarma.

\section{PENDAHULUAN}

Dewasa ini dapat dilihat sekeliling kita, bahwa banyak sekali tindak agresi yang meresahkan masyarakat. Agresivitas yang terjadi tentulah merugikan karena menimbulkan kerugian yang besar bagi korbannya. Agresivitas menjadi suatu perilaku yang menimbulkan kerugian bagi orang lain. Agresivitas yang ada di dalam masyarakat, dapat dituangkan ke dalam sebuah novel. Sebab novel berperan sebagai cerminan dari keadaan masyarakat.

Bila dalam novel pun menceritakan kisah agresivitas yang diciptakan pada berbagai tokoh dan bagaimana efek negatifnya, maka secara tidak langsung pembaca novel akan mengambil pesan moral, bahwa bertindak agresi akan merugikan banyak pihak.

Dalam kaitannya dengan bidang pendidikan tentu saja novel menjadi salah satu karya sastra yang cocok untuk diaplikasikan sebagai pelajaran sastra bagi siswa di sekolah. Mengacu pada kurikulum 2013 dengan silabus pendidikan SMK kelas XII semester ganjil pada kompetensi dasar 3.1 yaitu, 
memahami stuktur dan kaidah teks novel baik lisan maupun tulisan.

Dalam kompetensi dasar 3.1 tersebut, salah satunya siswa diharapkan dapat memahami struktur yang ada di dalam novel. Struktur tersebut mencakup struktur intrinsik dan ekstrinsik yang ada pada novel, unsur intrinsik tersebut antara lain tema, latar, alur, tokoh, sudut pandang. Tokoh memiliki peran penting dalam unsur intrinsik sebab di dalam novel pasti menceritakan tokoh, entah itu tokoh utama maupun tokoh sampingan.

Melalui pembelajaran sastra di sekolah yang mengacu pada kurikulum 2013 yang mengacu kepada silabus SMK kelas XII semester ganjil. Siswa diharapkan dapat memahami tokoh di dalam sebuah novel, sebab di dalam tokoh pada novel terdapat bentuk-bentuk tindakan psikologi manusia, salah satunya agresivitas. Agresivitas dalam tokoh pada novel, merupakan bagian dari ranah psikologi sastra.

Salah satu novel yang terdapat agresivitas di dalamnya adalah novel Jazz, Parfum dan Insiden karya Seno Gumira Ajidarma. Alasan novel Jazz, Parfum dan Insiden dipilih sebagai objek penelitian ini, karena di dalam novel ini yang paling menonjol adalah sisi agresivitasnya. Secara sadar ataupun tidak sadar, Seno memasukan unsur psikologi dalam novelnya yang dibeberkan melalui tokoh di dalamnya. Psikologi sastra yang jelas terlihat adalah agresivitas. Novel Jazz, Parfum dan Insiden berlatar pada peristiwa Timor Leste yang menjadi negara baru, yang berdiri secara resmi berdasarkan jajak pendapat tahun 1999. Dulunya, 
ketika masih bergabung dengan NKRI bernama Timor Timur, propinsi ke-27. Pemisahan diri Timor Timur ini, diwarnai dengan banyaknya tindakan agresi yang dilakukan oleh pihak yang kecewa dengan hasil referendum.

\section{Korrie Layun Rampan} mengatakan, "beberapa karya Seno Gumira Ajidarma menunjukkan kekuatan artistik yang secara radikal keluar dari mainstream sastra bisu dengan pembeberan fakta-fakta pelanggaran HAM dan sarkasme estetik yang diucapkan dengan cara yang sangat mengesankan."

Pernyataan tersebut menunjukkan bahwa, Seno terinspirasi dari fakta-fakta yang ada di masyarakat, fakta tersebut salah

2 Rampan, Korrie Layun. Sastra di Tengah Euforia (Jakarta: Kompas, 1999), h. 5. No. 014, Juli. satunya adalah agresivitas yang terdapat dalam diri manusia pada kehidupan nyata, yakni pada peristiwa Timor Timur. Kemudian, agresivitas tersebut direfleksikan oleh Seno Gumira Ajidarma ke dalam teks untuk menciptakan novel Jazz, Parfum dan Insiden. Tindakan agresivitas tersebut dapat dilihat pada tokoh yang terdapat dalam novel ini.

Tokoh-tokoh di dalam novel ini secara tidak langsung memiliki peran penting karena menjadi saksi, korban, bahkan pelaku agresivitas. Seperti tokoh utama yang diperankan oleh Aku di dalam novel ini digambarkan sebagai seorang wartawan di sebuah kantor kecil, kemudian mendapat banyak laporan dari sesama rekannya yang menulis berita mengenai agresivitas yang dilakukan oleh tentara, dengan korbannya adalah masyarakat 
Gidgid. Memang di dalam novel ini beberapa tokoh tidak disebutkan perorangan namun menyeluruh dengan menyebut kata tentara, masyarakat Gidgid, demonstran.

Agresi yang diceritakan di dalam novel ini cukup parah karena sampai ke dalam ranah pembunuhan, penganiayaan, pemerkosaan. Namun meski begitu, novel ini pun diselingi romansa perkelanaan tokoh aku dalam kehidupan cinta, dia banyak bertemu dengan wanita yang masingmasing wanita menyukai jenis parfum berbeda sesuai dengan kepribadiannya. Tokoh yang terdapat dalam penelitian ini, yaitu tokoh aku, tentara, demonstran, para saksi mata, Sasa, Rina. Namun, yang paling sering terlibat dalam tindakan agresi adalah tokoh tentara dan demonstran.

Subfokus dalam penelitian ini mengenai jenis-jenis, tujuan, penyebab, dampak dan solusi mengurangi agresivitas yang dilakukan oleh tokoh dalam novel Jazz, Parfum dan Insiden karya Seno Gumira Ajidarma.

Nursisto mendefinisikan, "novel adalah media penuangan pikiran, perasaan, dan gagasan penulis dalam merespon kehidupan baru di sekitarnya. Ketika di dalam kehidupan muncul permasalahan baru, nurani penulis novel akan terpanggil untuk segera menciptakan

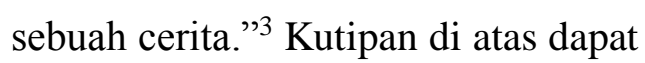
disimpulkan, dengan adanya novel pengarang dapat mengekspresikan apa yang dirasakan dan dialaminya, sebagai media penuangan pikiran pengarang.

Di dalam novel terdapat karakteristik yang membedakan antara novel dengan karya sastra

3 Nursisto, Ikhtisar Kesusastraan Indonesia, (Yogyakarta: Adicita Karya Nusa, 2000), h.168. 
yang lain. Dalam hal ini, Burhan

Nurgiyantoro mengatakan mengenai karakteristik novel yang bersifat mengikat karena berkaitan antara episode, berikut kutipannya:

Pemahaman secara keseluruhan cerita novel, dengan demikian seperti terputus-putus, dengan cara mengumpulkan sedikit demi sedikit pre-episode. Apalagi, sering, hubungan antar episode tidak segera dapat dikenali, walau secara teoretis tiap episode haruslah tetap mencerminkan tema dan logika cerita, sehingga boleh dikatakan bahwa hal itu bersifat mengikat adanya sifat saling berkaitan antara episode. $^{4}$

$$
\text { karakteristik novel selain }
$$
sifatnya yang realistik, juga bersifat mengikat. Mengikat antara satu episode dengan episode lainnya.

${ }^{4}$ Nurgiyantoro, Burhan. Teori Pengkajian Fiksi. (Yogyakarta: Gajah Mada University Press, 1998), h.11.
Novel tidak dapat berdiri sendiri dengan satu episode saja, atau dengan episode yang tidak saling mengikat satu sama lain. Oleh karena itu, sifat novel salah satunya adalah mengikat tiap episode, sehingga menghasilkan satu karya utuh yang berkesinambungan dan selaras.

Setelah kita mengetahui karakteristik novel, kemudian ada pendapat yang mempertanyaan perbedaan novel dan roman, untuk memperjelasnya, Semi mengatakan, dalam istilah novel tercakup pengertian roman; sebab roman hanyalah istilah novel untuk zaman sebelum perang dunia kedua di Indonesia. Istilah novel dikenal di Indonesia setelah kemerdekaan. Novel mengungkapkan suatu konsentrasi kehidupan pada suatu saat yang tegang, dan pemusatan kehidupan yang tegas: sedangkan 
roman dikatakan sebagai menggambarkan kronik kehidupan yang lebih luas yang biasanya melukiskan peristiwa dari masa kanak-kanak sampai dewasa dan meninggal dunia. ${ }^{5}$

Menurut kutipan di atas dapat disimpulkan, novel dan roman keduanya sama-sama saling beriringan berjalan. Dalam istilah novel pun, ada pengertian roman. Roman hadir terlebih dahulu di zaman sebelum perang kedua, dan kemudian istilah novel hadir setelahnya.

Di dalam sebuah novel terdapat tokoh yang memiliki peranan penting dalam penelitian ini. Wahyudi Siswanto mengatakan bahwa, "tokoh dalam karya rekaan selalu mempunyai sifat, sikap, tingkah laku atau watak-watak

5 M. Atar Semi, Anatomi Sastra, (Padang: Angkasa Raya, 1993), h.32. tertentu. Pemberian watak pada tokoh suatu karya oleh sastrawan disebut perwatakan." Dari kutipan di atas dapat diartikan, tokoh memiliki sifat tertentu yang dikreasikan oleh pengarang sesuai dengan kebutuhan penokohan.

\section{Penokohan dan perwatakan} sama saja hakikatnya, yakni keduanya sama-sama sebagai sifat, sikap, dan tingkah laku dari tokoh yang ada dalam novel. Tokoh tidak akan bisa berdiri sendiri tanpa adanya penokohan atau perwatakan. Tokoh haruslah memiliki sikap tertentu agar jalan cerita dapat berjalan dengan baik.

Di dalam tokoh kita dapat menesuri psikologi tokoh. Psikologi tersebut mencakup perilaku agresi. Agresi adalah siksaan yang disengaja

\footnotetext{
6 Siswanto, Wahyudi. Pengantar Teori Sastra. (Malang: Aditya Media Publishing, 2013), h.11.
} 
untuk menyakiti orang lain. ${ }^{7}$ Perilaku agresi ini sangat merugikan orang lain yang menjadi korbannya. Dalam bentuk luka fisik maupun psikologi.

Dalam penelitian ini menggunakan teori jenis agresivitas dari baron dan Byrne, yang terdiri dari, (i) Agersi langsung-aktif-verbal, (ii) Agresi langsung-aktif-nonverbal, Agresi, (iv) Agresi langsung-pasifnonverbal, (v) Agresi tidak langsungaktif-verbal, dan yang terakhir (vi) Agresi tidak langsung-aktifnonverbal. ${ }^{8}$

Kemudian, dalam faktor penyebab munculnya agresivitas menggunakan teori yang digagas oleh menurut Robert A. Baron. Robert A. Baron menggagas 5 faktor terrdiri dari frustasi, provokasi,

${ }^{7}$ Robert A Baron, Psikologi Sosial, terj. Ratna Djuwita, (Jakarta: Erlangga, 2003), h.170.

8 dr. Agus Abdul Rahman, Psikologi Sosial, (Jakarta: PT.Raja Grafindo Persada, 2014), h.197, h. 207-208. agresi yang dipindahkan, kekerasan media, dan keterangsangan yang meningkat. Peneliti menggunakan dua faktor dari lima faktor penyebab munculnya agresivitas menurut Robert A. Baron, yaitu frustasi dan provokasi.

\section{Dampak} agresivitas menggunakan teori yang digagas David M. Buss yang terdiri dari luka, kematian, serta kehilangan harkat dan martabat. Dalam solusi mengurangi agresivitas, peneliti menggunakan teroi Barbara Krahe yang terdiri dari tiga mekanisme yang mungkin bisa mencegah perilaku agresif telah dieksplorasi, yaitu hukuman, katarsis, dan mengelola amarah. ${ }^{9}$

Kegunaan teoritis penelitian ini bagi penulis, bermanfaat untuk menambah pengetahuan karya sastra

${ }^{9}$ Barbara Krahe, Perilaku Agresif, terj. Helly Prajitno, (Yogyakarta: Pustaka Pelajar, 2005), h. 354. 
Indonesia dalam hal agresivitas, psikoanalisis dan lain sebagainya. Kemudian bagi pengajar, pembelajar sastra, bahkan peminat serta masyarakat umum memperoleh kegunaan teoretis, yaitu mengembangkan serta memperluas pengetahuan akan agresivitas tokoh yang terdapat dalam novel Jazz, Parfum dan Insiden karya Seno Gumira Ajidarma.

Dalam penelitian ini juga memiliki beberapa kegunaan praktis, yaitu: dijadikan alat untuk membantu berbagai pihak, salah satunya pengajar sastra untuk lebih mengetahui perilaku agresivitas, penyebabnya, serta dampak buruk agresi yang ada dalam novel ini agar tidak ada yang mau melakukan tindakan agresi. Maka dengan penelitian agresivitas tokoh dalam novel Jazz, Parfum dan Insiden karya Seno Gumira Ajidarma ini dapat berguna baik secara teoretis maupun praktis.

\section{METODE PENELITIAN}

Penelitian ini bertujuan untuk mengetahui: 1. Jenis-jenis agresivitas tokoh dalam novel Jazz, Parfum dan Insiden karya Seno Gumira Ajidarma, 2. Tujuan dari agresivitas pada tokoh dalam dalam novel $\mathrm{Jazz}$, Parfum dan Insiden karya Seno Gumira Ajidarma, 3. Penyebab munculnya agresivitas tokoh dalam novel Jazz, Parfum dan Insiden karya Seno Gumira Ajidarma, 4. Dampak dari agresivitas tokoh dalam novel Jazz, Parfum dan Insiden karya Seno Gumira Ajidarma, 5.Solusi mengurangi perilaku agresivitas yang digunakan pada tokoh dalam novel Jazz, Parfum dan 
Insiden karya Seno Gumira

Ajidarma.

Penelitian ini bersifat studi kepustakaan. Metode yang digunakan yaitu deskriptif kualitatif dengan teknik analisis isi. Metode ini menganalisis agresivitas yang terdapat pada novel Jazz, Parfum dan Insiden karya Seno Gumira Ajidarma. Jenis penelitian ini dapat digolongkan ke dalam penelitian kualitatif. Menggunakan kajian psikologi sastra Carl Gustav Jung untuk mengupas agresivitas tokoh dalam novel ini.

Objek penelitian ini terdiri data dan sumber data. Data yang ada pada penelitian ini adalah agresivitas pada tokoh dalam novel Jazz, Parfum dan Insiden karya Seno Gumira Ajidarma, jenis-jenis agresivitas, penyebab munculnya agresivitas, dampak agresivitas, tujuan agresivitas, dan solusi mengurangi agresivitas yang menjadi sumber data adalah novel Jazz, Parfum dan Insiden karya Seno Gumira Ajidarma. Pada novel Jazz, Parfum dan Insiden karya Seno Gumira Ajidarma terdapat 26 cerita pengarang yang dibagi atas 26 bab. Dalam novel Jazz, Parfum dan Insiden mengusung tema kerusuhan Timor-Timur saat ingin memerdekakan diri dari NKRI dan menjadi negara bebas bernama Timor Leste yang di dalamnya terdapat beberapa perilaku agresif yang dilakukan tokoh-tokoh tertentu.

Dalam penelitian ini, peneliti menggunakan triangulasi sumber data dan juga triangulasi teori. Triangulasi sumber data yaitu mengumpulkan data dari berbagai sumber yang berbeda akan tetapi memiliki kesepadanan. Sumber data 
dalam hal ini dapat berupa tesis, maupun jurnal penelitian.

\section{TEMUAN DAN PEMBAHASAN}

\section{PENELITIAN}

Pada penelitian ini penulis menemukan temuan yang berkaitan dengan:

1. Jenis-jenis agresi

Terdapat jenis agresivitas yang digagas oleh Baron dan Byrne, yakni: (i) Agersi langsung-aktifverbal: memaki, membentak, berlagak atau memamerkan kekuasaan, (ii) Agresi langsungaktif-nonverbal: serangan fisik, baik mendorong, memukul, maupun menendang dan menunjukkan gestur yang menghina orang lain, (iii) Agresi langsung-pasif-verbal: diam, tidak menjawab panggilan telepon, (iv) Agresi langsung-pasifnonverbal: tidak memberi kesempatan target berkembangan, (v) Agresi tidak langsung-aktif-verbal: menyebarkan rumor negatif, menghinakan opini target pada orang lain, (vi) Agresi tidak langsung-aktifnonverbal: mencuri atau merusak barang target, menghabiskan kebutuhan yang diperlukan target. Jenis-jenis agresivitas tersebut dilakukan oleh tokoh tentara dan demonstran.

\begin{tabular}{|l|l|c|c|}
\hline No. & \multicolumn{1}{|c|}{ Jenis-jenis agresivitas } & Jumlah & Presentase \\
\hline 1. & Agresi langsung-aktif-verbal & 10 & $8,26 \%$ \\
\hline 2. & Agresi langsung-aktif- & 91 & $75,2 \%$ \\
\hline 3. & Agresi langsung-pasif-verbal & 2 & $1,62 \%$ \\
\hline 4. & Agresi langsung-pasif- & 11 & $9,09 \%$ \\
\hline
\end{tabular}




\begin{tabular}{|l|l|c|c|}
\hline & nonverbal & \\
\hline 5. & Agresi tidak langsung-aktif- & 4 & $3,30 \%$ \\
\hline 6. & Agresi tidak langsung-aktif- & 3 & $2,47 \%$ \\
& nonverbal & & \\
\hline Total & 121 & $100 \%$ \\
\hline
\end{tabular}

2. Tujuan agresi

Tujuan

agresi

yang

ditemukan dalam penelitian ini, berdasarkan teori

(1) Coercion

adalah agresi boleh jadi hanyalah perilaku kasar yang tujuannya bukan untuk melukai. Tujuan utamanya adalah untuk mengubah perilaku orang lain atau menghentikan perilaku orang lain yang dianggap tidak sesuai dengan apa yang diharapkan. (2) Power and dominance adalah perilaku agresi kadang ditunjukan untuk meningkatkan dan menunjukkan kekuasaan dan dominasi. Bagi orang yang menganggap penting dan ingin memelihara kekuasaan serta dominasinya, kekerasan kadang menjadi salah satu cara untuk menunjukannya. (3) Impression management adalah perilaku agresi kadang ditunjukkan dalam rangka menciptakan kesan. Orang yang konsep dirinya sebagai orang yang kuat ataupun berani, sering kali menggunakan agresi untuk memperteguh kesan yang ingin diciptakannya 


\begin{tabular}{|l|l|c|c|}
\hline No. & \multicolumn{1}{|c|}{ Tujuan agresivitas } & Jumlah & Presentasi \\
\hline 1. & Mengubah/menghentikan perilaku yang & 7 & $70 \%$ \\
\hline tidak sesuai & Kekuasaan dan dominasi & 3 & $30 \%$ \\
\hline 3. & Menciptakan kesan kuat dan berani & 0 & 0 \\
\hline \multicolumn{2}{|l|}{ Total } & 10 & $100 \%$ \\
\hline
\end{tabular}

3. Penyebab munculnya agresi

Dalam penelitian ini ditemukan penyebab munculnya agresi berdasarkan teori yang digagas Berkowitz. Berkowitz telah mengajukan ide bahwa frustasi merupakan suatu pengalaman tidak menyenangkan, dan frustasi dapat menyebabkan agresi sebagian besar karena adanya hubungan mendasar antara efek negatif (perasaan tidak menyenangkan) dengan perilaku agresif.

Kemudian, faktor yang kedua adalah provokasi, provokasi dapat menyebabkan agresi yang lebih kuat di hadapan seorang yang berhubungan dengan agresi (seperti senjata) daripada di hadapan seseorang yang netral.

\begin{tabular}{|l|l|c|c|}
\hline No. & \multicolumn{1}{|c|}{ Penyebab munculnya agresivitas } & Jumlah & Presentasi \\
\hline 1. & Frustasi & 1 & $25 \%$ \\
\hline 2. & Provokasi & 3 & $75 \%$ \\
\hline \multicolumn{2}{|l|}{ Total } & 4 & $100 \%$ \\
\hline
\end{tabular}


BAHTERA: Jurnal Pendidikan Bahasa dan Sastra, Volume 16 Nomor 2 Juli 2017 http://journal.unj.ac.id/unj/index.php/bahtera/

4. Dampak agresi

Dampak agresi ditemukan

dalam penelitian ini berdasarkan teori yang digagas David M.Buss

korban agresivitas yaitu menderita luka atau kematian, dan kehilangan harkat dan martabat.

\begin{tabular}{|l|l|c|c|}
\hline No. & \multicolumn{1}{|c|}{ Dampak agresivitas } & Jumlah & Presentase \\
\hline 1. & Luka & 9 & $42,8 \%$ \\
\hline 2. & Kematian & 12 & $57 \%$ \\
\hline 3. & Kehilangan harkat dan & 0 & 0 \\
\hline Total & & $100 \%$ \\
\hline
\end{tabular}

5. Solusi mengurangi agresi

Berdasarkan teori yang

digagas Barbara Krahe yang digunakan dalam penelitian ini, yaitu

hukuman, katarsis, dan mengelola

amarah

\begin{tabular}{|l|l|c|c|}
\hline No. & \multicolumn{1}{|c|}{$\begin{array}{c}\text { Solusi mengurangi } \\
\text { agresivitas }\end{array}$} & Jumlah \\
\hline 1. & Hukuman & 9 & $90 \%$ \\
\hline 2. & Katarsis & 0 & 0 \\
\hline 3. & Mengelola Amarah & 1 & $10 \%$ \\
\hline \multicolumn{2}{|l|}{ Total } & 10 & $100 \%$ \\
\hline
\end{tabular}




\section{SIMPULAN DAN SARAN}

Simpulan yang ada dalam penelitian ini dapat dijabarkan sebagai berikut:

1. Jenis-jenis agresivitas pada tokohtokoh yang paling banyak ditemukan adalah jenis agresilangsung-aktif-nonverbal dengan jumlah $91(75,2 \%)$, sedangkan yang paling sedikit ditemukan adalah jenis agresi langsung-pasifverbal sebanyak $2(1,62 \%)$, untuk jenis agresi langsung-akrif-verbal ditemukan sebanyak $10(8,26 \%)$. Untuk agresi langsung-pasifnonverbal 11 (9,09\%), kemudian untuk agresi tidak langsung-aktifverbal ditemukan sejumlah 4 $(3,30 \%), \quad$ dan agresi tidak langsung-aktif-nonverbal ditemukan sebanyak $3(2,47 \%)$. Maka, dapat disimpulkan jenis agresivitas terbanyak yang ditemukan dalam penelitian ini adalah jenis agresivitas langsungaktif-nonverbal dengan jumlah 91 $(75,2 \%)$

2. Tujuan agresivitas pada tokohtokoh dalam novel Jazz, Parfum, dan Insiden karya Seno Gumira Ajidarma yang paling banyak ditemukan adalah tujuan agresivitas untuk mengubah atau menghentikan perilaku yang tidak sesuai, dengan data yang ditemukan sebanyak 7 (70\%), sedangkan untuk tujuan kekuasaan dan dominasi ditemukan 3 (30\%), yang terakhir adalah tujuan agresi untuk menciptakan kesan kuat dan berani tidak ditemukan sama sekali dalam penelitian ini. Dapat disimpulkan, tujuan agresivitas yang dominan dalam penelitian ini adalah tujuan agresivitas untuk 
mengubah atau menghentikan perilaku yang tidak sesuai dengan temuan sejumlah $7(70 \%)$.

3. Penyebab munculnya agresivitas pada tokoh-tokoh dalam novel Jazz, Parfum, dan Insiden karya Seno Gumira Ajidarma ditemukan yang paling banyak adalah faktor provokasi dengan data yang ditemukan sebanyak $3(75 \%)$, sedangkan faktor frustasi ditemukan sebanyak 1 (25\%).

4. Dampak agersivitas pada tokohtokoh dalam novel Jazz, Parfum, dan Insiden karya Seno Gumira Ajidarma ditemukan yang paling banyak adalah dampak agresivitas berupa kematian dengan jumlah 12 (42,8\%), kemudian dampak agresivitas berupa luka ditemukan sejumlah $9(57 \%)$, sedangkan dampak agresivitas berupa kehilangan harkat dan martabat tidak ditemukan dalam penelitian ini. Maka, dampak agresivitas yang paling dominan dalam penelitian ini adalah dampak agresivitas berupa kematian dengan data sejumlah $12(42,8 \%)$.

5. Solusi mengurangi agresivitas pada tokoh-tokoh dalam novel Jazz, Parfum, dan Insiden karya Seno Gumira Ajidarma yang dominan ditemukan adalah solusi mengurangi agresivitas berupa hukuman ditemukan sebanyak 9 (90\%), sedangkan mengelola emosi sejumlah 1 (10\%), dan katarsis tidak ditemukan sama sekali dalam penelitian ini.

Berdasarkan hasil penelitian serta teori-teori yang dijadikan landasan dapat direkomendasikan bahwa melalui novel Jazz, Parfum, dan Insiden karya Seno Gumira Ajidarma dapat tergambarkan 
agresivitas pada tokoh-tokohnya, agresivitas yang ternyata terbagi menjadi beberapa jenis, tujuan tokoh melakukan agresivitas dalam novel, kamudian juga penyebab munculnya agresivitas pada tokoh, lalu dampak yang ditimbulkan pada tokoh ketika melakukan aksi agresivitas, dan solusi tokoh dalam mengurangi aksi agresi itu sendiri dapat diketahui dalam novel ini. Bagaimana agresivitas tersebut dapat muncul kita dapat mengetahuinya dan bisa mengantisipasi apabila agresivitas terjadi dalam kehidupan kita sendiri.

Dari kelebihan yang terdapat dalam novel Jazz, Parfum, dan Insiden karya Seno Gumira Ajidarma yang diperoleh dari penelitian ini, dapat digunakan sebagai alternatif sumber pelajaran bahasa Indonesia bagi siswa di SMA/K. Guru serta siswa dapat mempelajari bahwa aksi agresivitas yang bersifat negatif bukanlah aksi yang pantas untuk ditiru dan sebaiknya dihindari sedangkan aksi agresi yang positif untuk pertahanan diri di kala terdesak bisa saja dilakukan. Saran dari penelitian ini adalah, penelitian ini masih jauh dari kata sempurna oleh karena itu penelitian ini dapat dijadikan penelitian lanjutan untuk para peneliti selanjutnya.

\section{DAFTAR PUSTAKA}

Ajidarma, Seno Gumira. Jazz, Parfum dan Insiden Jakarta: Gramedia Pustaka Utama, 2017.

Baron, Robert. A. Psikologi Sosial, terj. Ratna Djuwita. Jakarta: Erlangga, 2005.

Krahe, Barbara. Perilaku Agresif, terj. Helly Prajitno. Yogyakarta: Pustaka Pelajar, 2005. 
BAHTERA: Jurnal Pendidikan Bahasa dan Sastra, Volume 16 Nomor 2 Juli 2017 http://journal.unj.ac.id/unj/index.php/bahtera/

Nurgiyantoro, Burhan. Teori

$$
\begin{array}{ll}
\text { Pengkajian } & \text { Fiksi. } \\
\text { Yogyakarta: Gajah } & \text { Mada } \\
\text { University Press,1998. } &
\end{array}
$$

Nursisto. Ikhtisar Kesusastraan

Indonesia. $\quad$ Yogyakarta:

Adicita Karya Nusa, 2000.

Semi, M. Atar. Anatomi Sastra.

Padang: Angkasa Raya, 1993.

Siswanto, Wahyudi. Pengantar Teori

Sastra. Malang: Aditya

Media Publishing, 2013.

Rampan, Korrie Layun "Sastra di Tengah Euforia” Kompas, No. 014, Juli, 1999, hlm. 5 